Jurnal Health Sains: p-ISSN: 2723-4339 e-ISSN: 2548-1398

Vol. 2, No. 3, Maret 2021

\title{
ANALISA FAKTOR YANG MEMPENGARUHI KUALITAS TIDUR LANSIA DI PANTI
}

\author{
Rizki Jian Utami, Retno Indarwati dan Retnayu Pradanie
}

Universitas Airlangga Surabaya Jawa Timur, Indonesia

Email: jianutami22@gmail.com, retno-i@fkp.unair.ac.id dan retnayu-p@fkp.unair.ac.id

\begin{tabular}{|c|c|}
\hline ARTIKEL INFO & ABSTRACT \\
\hline $\begin{array}{l}\text { Tanggal diterima: } 5 \text { Maret } 2021 \\
\text { Tanggal direvisi: } 15 \text { Maret } 2021 \\
\text { Tanggal disetujui: } 25 \text { Maret } \\
2021\end{array}$ & $\begin{array}{l}\text { The research method of searching journals or articles } \\
\text { using Scopus, Proquest, Pubmed and science Direct } \\
\text { indexed databases uses strong keywords. The Centre for } \\
\text { Review and Dissemination and The Joanna Briggs }\end{array}$ \\
\hline $\begin{array}{l}\text { Keywords: } \\
\text { sleep disorders; sleep quality; } \\
\text { elderly homes }\end{array}$ & $\begin{array}{l}\text { Institute are used to assess the quality of research. The } \\
\text { framework used to review is PICOS and the inclusion } \\
\text { criteria used are English and Indonesian journals with } \\
\text { publications from } 2015 \text { to 2020. Analyze and tabulate } \\
\text { data in articles or journals. Titles, abstracts, full text and } \\
\text { methodologies are assessed to determine the feasibility of } \\
\text { an article or journal. The results of one thousand eight } \\
\text { hundred and twenty-six identified, there are fifteen } \\
\text { articles that fit the criteria of the study. Factors that affect } \\
\text { sleep quality include environment, psychological stress, } \\
\text { nutrition, lifestyle, physical activity, exercise. While how } \\
\text { to improve the quality of sleep is brain gym, therapeutic } \\
\text { touch, cognitive training, footbath theraphy, } \\
\text { aromatheraphy, reminiscene therapy, acupressure. } \\
\text { Environmental conclusions are one of the factors that } \\
\text { most affect the quality of sleep of the elderly in this } \\
\text { search, while one of the most effective ways to improve } \\
\text { the quality of elderly sleep is the use of aromatherapy. }\end{array}$ \\
\hline
\end{tabular}

\section{ABSTRAK}

Metode penelitian pencarian jurnal atau artikel menggunakan database yang terindeks Scopus, Proquest, Pubmed dan science Direct menggunakan kata kunci yang adekuat. The Centre for Review and Dissemination and The Joanna Briggs Institute digunakan untuk menilai kualitas penelitian. Framework yang digunakan untuk mereview adalah PICOS dan kriteria inklusi yang digunakan yakni jurnal berbahasa Inggris dan Indonesia dengan terbitan tahun 2015 sampai 2020. Dilakukan analisis dan tabulasi data pada artikel atau jurnal. Judul, abstrak, teks lengkap dan metodologi dinilai untuk menentukan kelayakan artikel atau jurnal. Hasil penelitian seribu delapan ratus dua puluh enam diidentifikasi, terdapat lima belas artikel yang sesuai dengan kriteria penelitian. Faktor-faktor yang mempengaruhi kualitas tidur diantaranya lingkungan, stress psikologi, gizi, gaya hidup, aktivitas fisik, Olahraga. Sedangkan cara 
Kata Kunci:

gangguan tidur; kualitas tidur; panti lansia meningkatkan kualitas tidur adalah brain gym, therapeutic touch, cognitive training, footbath theraphy, aromatheraphy, reminiscene therapy, acupressure. Kesimpulan lingkungan menjadi salah satu faktor yang paling mempengaruhi kualitas tidur lansia di panti, sedangkan salah satu cara yang cukup efektif untuk meningkatkan kualitas tidur lansia adalah penggunaan aromatherapy.

Coresponden Author:

Email: jianutami22@gmail.com

Artikel dengan akses terbuka dibawah lisensi

\section{Pendahuluan}

Kualitas tidur merupakan masalah dominan yang hampir dimiliki semua lansia. (Yücel et al., 2020). Lansia merupakan manusia yang memasuki tahap akhir dari suatu fase kehidupan. Menurut (Organization, 2015) lansia adalah individu yang berusia 60 tahun keatas yang terdiri dari lansia awal yaitu umur 60-74 tahun, lansia menengah dengan rentan umur 75-90 tahun dan lansia akhir yaitu lansia dengan umur 90 tahun keatas. Kualitas tidur merupakan kepuasan seseorang terhadap tidur, sehingga seseorang tersebut tidak memperlihatkan tanda-tanda kurang tidur dan tidak mengalami masalah dalam tidurnya. Kualitas tidur mencakup durasi tidur, latensi tidur, serta aspek subjektif seperti tidur malam dan istirahat. Kualitas yang baik dilihat dari kebugaran, kesehatan dan bagaimana seseorang itu terlihat segar di pagi hari. (Prastyo et al., 2017).

Masalah kualitas tidur pada lansia seharusnya dapat menjadi perhatian yang lebih karena jika dibiarkan dapat menyebabkan berbagai macam hal yang merugikan baik untuk kesehatan tubuh ataupun menurunkan angka harapan hidup lansia (Cherukuri et al., 2018). Secara khusus lansia di panti melaporkan tingkat stress yang lebih tinggi karena kondisi tempat tinggal yang mereka tempati, hal ini menyebabkan kualitas tidur yang buruk. dibuktikan dengan adanya proses adaptasi lingkungan baru, kebiasan dan pola hidup yang berbeda antar lansia (Kim et al., 2016). Hasil Penelitian (Brewster et al., 2019) menunjukan bahwa lingkungan yang bising, kotor dan sempit dapat berdampak negatif pada fisiologis, perilaku dan fungsi kognitif lansia, hal ini dapat mengganggu tidur yang pada akhirnya mempengaruhi kualitas tidur lansia.

Berdasarkan data proyeksi penduduk Kementerian RI tahun 2017, diperkirakan jumlah penduduk lansia adalah 23,66 juta jiwa $(9,03 \%)$. Prediksi jumlah lansia pada tahun 2020 (27,08 juta), tahun 2025 (33,69 juta), tahun 2030 (40,95 juta) dan tahun 2035 (48,19 juta). Persentase penduduk lansia di Jawa Timur telah mencapai $12,92 \%$ dari keseluruhan penduduk (BPS JATIM, 2017). Manurut hasil survei CDC (CentersforDisease-Controland Prevention) diperkirakan 50 - 70 juta orang Amerika mengalami gangguan tidur. Semakin bertambahnya usia seseorang kemungkinan mengalami gangguan tidur 5\% pada usia 30 50 tahun, dan $30 \%$ pada usia diatas 50 tahun. Di Indonesia, setiap tahun diperkirakan sekitar 35\%-45\% orang dewasa melaporkan adanya gangguan tidur dan sekitar $25 \%$ mengalami gangguan tidur yang serius. Prevalensi gangguan tidur pada dewasa cukup tinggi yaitu sekitar 50\% (RI, 2012). 
Faktor-faktor yang mempengaruhi kualitas tidur lansia yang adalah stress psikologis, gizi, lingkungan, motivasi, gaya hidup dan olahraga (Nursalam et al., 2018). Lingkungan adalah faktor penting untuk penerapan sleep hygiene. Kepadatan dan luas kamar, pencahayaan terlalu terang, kebisingan dari kegiatan panti dan kebersihan lingkungan yang diciptakan antar individu (Brewster et al., 2019). Faktor Psikologis yang menyebabkan gangguan tidur pada lansia panti sangat beragam. Antara lain seperti kisah hidup traumatis, masalah rumah tangga terdahulu, kekhawatiran masa kini dan masa depan, mimipi buruk dan perasaan gelisah. Lansia yang stress dan memilih menghabiskan waktu siang nya untuk tidur dapat memicu gangguan tidur di malam hari. Hal ini mempengaruhi kualitas tidur secara negatif pada lansia (Aşiret \& Dutkun, 2018). Status kesehatan lanjut usia dipengaruhi oleh faktor gizinya. Status gizi pada lanjut usia harus mendapatkan perhatian khusus karena dapat mempengaruhi status kesehatan, penurunan kualitas tidur, kualitas hidup dan mortalitas. Gizi kurang maupun gizi lebih pada masa dewasa akhir dapat memperburuk kondisi fungsional dan kesehatan fisik (Morehen et al., 2020). Sedangkan faktor gaya hidup dan aktivitas fisik dipengaruhi oleh keaktifan lansia sehari-hari, kebiasaan menghabiskan waktu harian hal ini terkait dengan imobilitas yang dihubungkan dengan tirah baring. Bedrest kronis mengganggu ritme sikardian / dan ritme waktu tidur. Terlalu lama berbaring di tempat tidur di siang hari menyebabkan episode bangun pendek di malam hari dan kualitas tidur lansia menjadi buruk (Martin et al., 2017).

Gangguan tidur meningkat lebih buruk seiring bertambahnya usia. Kualitas tidur yang buruk pada lansia dapat dikaitkan dengan adanya masalah fisik, mental dan kesejahteraan sosial (Zhu et al., 2020). Gangguan tidur pada lansia panti dapat di atasi dengan beberapa intervensi antara lain brain gym, therapeutic touch, cognitive training, footbath theraphy, aromatheraphy, reminiscene therapy, acupressure.

\section{Metode Penelitian}

Pencarian literature dilakukan pada bulan Mei - Juli 2020 dengan menggunakan data sekunder. Perumusan pertanyaan penelitian menggunakan PICOS (Population /Problem, Interest/Intervention, Comparison, Outcome dan Study design) dan menggunakan kata kunci yang disesuaikan dengan Medical Subject Heading (MeSH) yaitu Sleep Disturbance OR Sleep Disorder OR Sleep wake AND Sleep Hygiene OR Sleep Habits AND Sleep Quality AND Elderly OR Aged OR Older OR Adult AND Nursing Home.

Pencarian artikel didapatkan dari database Scopus, Sciencedirect, Proquest dan Pubmed menggunakan kata kunci yang dipilih dan dipublikasikan 5 tahun terakhir yaitu pada rentang tahun 2016 - 2020 dengan artikel berbahasa inggris, dapat diakses secara fulltext dan open access.

Artikel yang ditemukan sebanyak 1826, emudian dilakukan seleksi duplikat menggunakan mendeley sebanyak 425 artikel. Tahap berikutnya yakni melakukan screening terhadap topic yang tidak relevan sebanyak 304 artikel, pengeliminasian dilakukan pada artikel yang tidak memenuhi kriteria inklusi dimana tidak fokus pada Sleep Hygiene sebanyak 11 artikel kriteria yang tidak fokus pada sleep quality sebanyak 15 artikel, eliminasi pada artikel systematic review 16 artikel, literature review 10 artikel, book chapters 20 Artikel, dan conference abstrac 24 artikel. Setelah ditemukan 25 artikel abstrak selanjutnya peneliti melakukan screening menyeluruh. Pengeleminasian dilakukan pada artikel yang tidak fokus pada analisa faktor 5 (lima) artikel dan artikel yang tidak berfokus pada lansia yang tinggal di panti 5 (lima) artikel. Sehingga artikel yang 
digunakan dalam penelitian ini adalah 15 artikel.

Penilaian kualitas dalam studi literature review ini menggunakan The Joanna Briggs Institute (JBI) Critical Appraisal dan CRAAP test (Currency, Relevance, Authority, Accuracy and Purpose).

\section{Hasil dan Pembahasan}

\section{Hasil Penelitian}

Hasil pencarian artikel didapatkan faktor yang mempengaruhi kualitas tidur lansia di panti

\section{a. Faktor yang mempengaruhi Kualitas}

\section{Tidur Lansia}

1) Faktor Lingkungan

Populasi lansia di panti meningkat setiap tahunnya, di Amerika serikat peningkatan lansia yang tinggal di panti naik $43 \%$ setiap bulan. Hal ini berpengaruh pada kepadatan penduduk panti dan kenyamanan lansia. Lingkungan adalah faktor penting seperti kepadatan dan luas kamar, pencahayaan terlalu terang, kebisingan dari kegiatan panti dan kebersihan lingkungan yang diciptakan antar individu (B. Chen, 2019). Hasil Penelitian (Brewster et al., 2019) menunjukan bahwa lingkungan yang bising, kotor dan sempit dapat berdampak negatif pada fisiologis, perilaku dan fungsi kognitif hal ini dapat mengganggu tidur yang pada akhirnya mempengaruhi kualitas tidur lansia. Pada penelitian (Li \& Jiang, 2020) lansia mengeluh tidak bisa tidur karena lingkungan yang kotor dan berbau. $70 \%$ lansia mengaku tidak nyaman dengan bau busuk yang mengganggu tidur mereka. Lansia panti memiliki beraneka ragam sifat, budaya dan kebiasaan.
Perbedaan ini mampu memicu kebisingan, mempengaruhi kebersihan kamar serta ikut serta dalam menciptakan suasana nyaman (Yeung et al., 2018).

2) Faktor Stress Psikologi

Lansia yang tinggal di panti berasal dari berbagai latar belakang yang berbeda. Hal ini membuat faktor stress antar lansia satu dan yang lainya beberbeda. Lansia yang tinggal di panti mengalami kesulitan beradaptasi sehingga merasa stres, kehilangan kontrol atas hidupnya, kehilangan identitas diri (Elvina et al., 2017). Menurut penelitian (Zhu et al., 2020) faktor psikologis yang menyebabkan gangguan tidur pada lansia panti sangat beragam. Antara lain seperti kisah hidup traumatis, masalah rumah tangga terdahulu, kekhawatiran masa kini dan masa depan, mimipi buruk dan perasaan gelisah. Lansia yang stress dan memilih menghabiskan waktu siang nya untuk tidur dapat memicu gangguan tidur di malam hari. Hal ini mempengaruhi kualitas tidur secara negatif. Menurut (Aşiret \& Dutkun, 2018) penelitian menunjukkan bahwa lansia yang tidak mengalami stres cenderung tidak akan terjadi gangguan pada kualitas tidurnya, sebaliknya sebagian besar lansia yang megalami stres ringan dan terjadi gangguan tidur sebanyak 34 $(89,5 \%)$ responden, hasil tersebut menunjukkan bahwa tingkat stres berpengaruh terhadap kualitas tidur pada lansia. Adanya hubungan tingkat stres dengan kualitas tidur terjadi karena lansia yang mengalami stres ringan cenderung terjadi gangguan pada kualitas 
tidurnya, sedangkan lansia yang tidak mengalami stres cenderung tidak terjadi gangguan pada kualitas tidurnya. Hal tesebut menunjukkan bahwa semakin tinggi tingkat stres yang dialami oleh lansia maka akan semakin besar resiko terjadi gangguan pada kualitas tidurnya. Pada penelitian (Gordon \& Gladman, 2010) aktivitas fisik yang baik dapat mempengaruhi psikologi dan stress lansia secara signifikan, lansia melaporkan lebih bahagia setelah menghabiskan waktunya dengan berolahraga selain itu mood lansia membaik dan lansia cenderung dapat mengendalikan emosi nya, sehingga mempengaruhi kualitas tidur lansia. Lingkungan juga mempengaruhi tingkat stress lansia yang tinggal di panti, lansia yang tinggal di panti mengaku bahwa kondisi di panti jauh berbeda dengan kondisi di rumah. Hal ini memakan waktu untuk lansia bisa menerima dan beradaptasi. Namun tidak sedikit lansia yang pada akhirnya stress dan tidak bisa beradaptasi dengan baik secara cepat (Yeung et al., 2018).

3) Faktor Gizi

Kondisi fisik yang baik akan mendukung lanjut usia memiliki gaya hidup yang baik, sehingga meningkatkan status kesehatannya. Status kesehatan lanjut usia dipengaruhi oleh faktor gizinya. Status gizi pada lanjut usia harus mendapatkan perhatian khusus karena dapat mempengaruhi status kesehatan, penurunan kualitas tidur, kualitas hidup dan mortalitas. Gizi kurang maupun gizi lebih pada masa dewasa akhir dapat memperburuk kondisi fungsional dan kesehatan fisik (Morehen et al.,
2020). Faktor gizi sangat penting karena berdasarkan penelitian (Lee et al., 2020) mengonsumsi makanan berlemak, siap saji dan makanan tidak sehat secara berlebihan dapat mempengaruhi tidur karena mampu menyebabkan gangguan pencernaan, perut mulas dan tenggorokan panas. Hal ini dapat menyebabkan lansia akan mudah terbangun di malam hari atau sulit untuk kembali memulai tidur dan mempertahankan kualitas tidur yang baik

4) Faktor Gaya Hidup

Kualitas tidur yang buruk adalah masalah umum pada lansia, hal ini dapat dipengaruhi dari perubahan aktivitas dan memiliki keterkaitan dengan pekerjaan (Zhu et al., 2020). Gaya hidup di siang hari juga dapat berkontribusi sebagai masalah tidur lansia panti. Rutinitas panti jompo mendorong ketidakaktifan lansia. Lansia di panti cenderung malas melakukan kegiatan di siang hari. Mereka tidak perlu memasak karena panti sudah menyediakan kebutuhan pangan, panti juga menyediakan tukang bersih-bersih untuk mengepel dan menyapu panti, kebanyakan panti juga menggunakan jasa laundry untuk mencuci baju lansia. (Yücel et al., 2020). Sehingga menurut penelitian (Martin et al., 2017) lansia akan meninggalkan tempat tidurnya disaat ada kegiatan penting yang diselenggarakan dan lebih memilih berdiam diri diatas tempat tidur seharian untuk bermalasmalasan.

5) Faktor Olahraga / Aktivitas Fisik

Aktivitas fisik merupakan faktor penting untuk menjaga kesehatan pada lansia. Orang lanjut 
usia hampir dua kali lebih mungkin memiliki cacat fisik atau mental dan empat kali lipat lebih mungkin memiliki beberapa keterbatasan fisik, dibandingkan dengan orang berusia $<60$ tahun (Lee et al., 2020). Menurut penelitian (Štefan et al., 2018) lansia yang tidur terlalu lama dan terlalu pendek cenderung tidak berolahraga secara teratur. Pada penelitian ini juga dijelaskan lansia yang tidur kurang dari 4 jam cenderung kurang aktif dan memiliki aktivitas fisik yang buruk dibandingkan dengan lansia yang tidur dengan durasi lebih dari 7-8 jam. Menurut penelitian (Iyer et al., 2019). Lansia Insomnia yang lebih tua menunjukkan distribusi aktivitas fisik yang relatif kurang hal ini terkait dengan imobilitas yang dihubungkan dengan tirah baring. Bedrest kronis mengganggu ritme sikardian/dan ritme waktu tidur. Terlalu lama berbaring di tempat tidur di siang hari menyebabkan episode bangun pendek di malam hari dan kualitas tidur lansia menjadi buruk.

6) Kualitas tidur pada lansia

Kualitas tidur merupakan kepuasan seseorang terhadap tidur, sehingga seseorang tersebut tidak memperlihatkan tanda-tanda kurang tidur dan tidak mengalami masalah dalam tidurnya. Kualitas tidur mencakup durasi tidur, latensi tidur, serta aspek subjektif seperti tidur malam dan istirahat. Kualitas yang baik dilihat dari kebugaran, kesehatan dan bagaimana seseorang itu terlihat segar di pagi hari ( $\mathrm{Li} \&$ Jiang, 2020) Masalah kualitas tidur pada lansia seharusnya dapat menjadi perhatian yang lebih karena jika dibiarkan dapat menyebabkan berbagai macam hal yang merugikan baik untuk kesehatan tubuh ataupun menurunkan angka harapan hidup lansia. (Cherukuri et al. 2018). Secara khusus lansia di panti melaporkan tingkat stress yang lebih tinggi karena kondisi tempat tinggal yang mereka tempati, hal ini menyebabkan kualitas tidur yang buruk. dibuktikan dengan adanya proses adaptasi lingkungan baru, kebiasan dan pola hidup yang berbeda antar lansia. (Kim et al., 2016). Sebagian lansia memiliki masalah tidur, yang berdampak pada kualitas hidup dan kesehatan, di dukung dengan beberapa faktor seperti faktor penuaan, faktor lingkungan dan penyakit penyerta. (Yücel et al., 2020). Masalah tidur meningkat lebih buruk seiring bertambahnya usia. Kualitas tidur yang buruk pada lansia dapat dikaitkan dengan adanya masalah fisik, mental dan kesejahteraan sosial (Zhu et al., 2020).

\section{b. Intervensi untuk Meningkatkan Kualitas Tidur Lansia}

1)Brain Gym (Senam Otak)

Senam otak merupakan salah satu kegiatan yang bertujuan untuk menjaga kesehatan otak dengan gerakan sederhana. Pada prinsipnya, inti dari senam otak adalah melatih otak agar tetap fit dan menghilangkan stress. Brain Gym juga merupakan intervensi aktivitas fisik lansia dengan frekuensi, intensitas, waktu dan tipe yang cocok dengan kriteria FITT untuk lansia. Senam otak lansia dilatih untuk mampu memberikan respon relaksasi sehingga dapat mencapai keadaan tenang (Nursalam et al., 
2018). Menurut penelitian (Nursalam et al., 2018) setelah dilakukan intervensi senam otak atau Brain Gym selama 16 minggu di panti, kualitas tidur pada lansia meningkat secara signifikan, mood meningkat dengan hasil stress menurun. Sehingga intervensi Brain gym efektif untuk meningkatkan kualitas tidur lansia.

2) Therapeutic Touch

Therapeutic touch atau terapi sentuhan merupakan terapi pengobatan holistik yang validitasnya sudah terbukti. Terapi sentuhan memungkinkan individu untuk menemukan keseimbangan batin yang berfungsi untuk mengurangi stress, terapi ini merupakan pengobatan sederhana dan non invasif tanpa biaya, tanpa efek samping dan tindakan medis. Terapi sentuhan terbukti memiliki efek seperti mengurangi rasa sakit, kecemasan, depresi dan kelelahan, meningkatkan kualitas hidup dan kualitas tidur, mengatur tekanan darah dan jantung, memberikan relaksasi dan kenyamanan. Menurut penelitian (Yücel et al., 2020) terapi sentuhan efektif dalam mengurangi nyeri dan meningkatkan rasa nyaman, sehingga dapat meningkatkan kualitas tidur.

3) Cognitive Training

Latihan kognitif merupakan suatu pengobatan rehabilitasi yang berfungsi untuk meningkatkan kemampuan individu yang mengalami masalah neurologis karena fenomena penyakit atau faktor penuaan (Thiele et al., 2014). Latihan kognitif digunakan sebagai alat untuk membantu mencapai tujuan terapeutik yang ditargetkan seperti meningkatkan harga diri dan melatih lansia untuk mengembangkan strategi pemecahan masalah. Tujuan dari latihan kognitif adalah untuk meningkatkan memori, perhatian, presepsi, penalaran, perencanaan, penilaian pembelajaran umum dan fungsi otak. Beberapa penelitian telah menunjukkan bahwa mengembangkan kemampuan kognitif ini dapat mengarah pada peningkatan kesadaran diri, kepercayaan diri, dan stabilitas emosional (Zhu et al., 2020). Menurut penelitian (Almondes et al., 2017) fungsi kognitif juga dipengaruhi oleh penuaan yang sehat. Penelitihan terbaru juga menyatakan bahwa ada hubungan antara kualitas tidur yang buruk pada lansia dengan fungsi kognitif yang buruk. Dalam penelitian ini juga diterangkan bahwa intervensi ini juga efektif untuk mencapai kondisi tidur yang sehat. Sehingga lansia yang mempunyai fungsi kognitif yang terlatih akan dapat mencapai kualitas tidur yang baik.

4) Footbath Therapy

Terapi Footbath (rendam kaki) telah terbukti efektif dalam meningkatkan kualitas tidur karena mampu menurunkan suhu inti tubuh melalui vasodilatasi perifer. Terapi Footbath mampu meningkatkan kualitas tidur dengan mengurangi latensi onset tidur, meningkatkan fase tidur NREM, dan mengurangi tidur REM. Selain itu terapi ini mudah dilakukan dan hemat biaya. Efek terapi footbath bervariasi tergantung pada suhu air, lama terapi dan subjek terapi. Menurut penelitian (Lee et al., 2020) terapi footbath yang dilakukan dengan suhu $40^{\circ} \mathrm{C}$ dalam waktu 30 menit 
dan jangka 4 mimggu dapat meningkatkan kualitas tidur lansia dengan gangguan tidur buruk, sebaliknya terapi ini tidak mempengaruhi lansia dengan kualitas tidur yang baik. Walaupun terapi footbath ini memberikan peningkatan kualitas tidur pada lansia, namun terapi ini tidak secara langsung menghasilkan perbaikan perilaku gangguan tidur pada lansia.

5) Aromatherapy

Aromatherapy merupakan intervensi yang mengacu pada pengobatan terapeutik yang diserap melalui indra penciuman atau melalui kulit. Aromatherapy yang paling sering digunakan dalam meningkatkan kualitas tidur lansia adalah Langon Kleri (Salvia Scarea), Eukalipus (EucalyptusGlobulus), Geranium (Pelargonium Graveolens), Lavender (Lavendula Vera Officianals), Lemon (Citrus Linonem), Peppermint (Mentha Piperita), Petitgrain (Daun Citus Aurantium), dan Rosmari (Rosmarinus Officinals), serta Pohon teh (Melalueca Alternifol) (Li \& Jiang, 2020). Aromatheraphy sangat efektif dalam meningkatkan kenyamanan, pengurangan nyeri, relaksasi, pengembangan mekanisme koping, pengurangan stress, dan meningkatkan kesejahteraan lansia. Kandungan aromatherapy yang mampu mempengaruhi kualitas tidur lansia antara lain kandungan linalool dan linalyl acetate. Linalool berfungsi sebagai obat penenang dengan mempengaruhi reseptor asam aminobutirat di pusat saraf yang menyebabkan peningkatan sekresi serotonin yang signifikan dari sistem pencernaan. Selain itu aromatherapy juga mempunyai kandungan fenol adehida atau alkohol, yang berfungsi untuk menimbulkan efek sedatif pada amigdala otak dan memicu kantuk (Tao-juan et al., 2019). Menurut penelitian (Faydali \& Çetinkaya, 2018) ada peningkatan yang signifikan pada pemberian aromatherapy lavender untuk lansia dengan gangguan tidur kronis. Kualitas tidur dan kuantitas tidur lansia meningkat dan lansia dapat mencapai tingkat tidur NREM. Selain itu beberapa lansia panti menyatakan aromatherapy membantu meningkatkan rasa nyaman karena membantu menghilangkan bau tidak sedap, memberikan ketenangan, dan membantu mengurangi nyeri.

6) Reminiscence Therapy

Salah satu terapi non farmakologis yang terbukti mampu mengurangi gangguan tidur orang tua adalah terapi reminiscene. terapi reminiscene dilakukan dengan cara mengingat peristiwa masa lalu dan fokus pada meningkatkan kualitas kehidupan di masa sekarang. Terapi reminiscene ini dilakukan oleh profesional keperawatan baik dengan individu ataupun kelompok. Terapi ini menggunakan media musik, album foto masa lalu dan barang pribadi yang menunjang. Banyak penelitian membuktikan bahwa terapi ini mampu menurunkan depresi, kecemasan dan meningkatkan harapan dan kepuasan hidup. Selain itu terapi reminiscnene menunjukkan efek positif pada kualitas tidur lansia. 
Menurut penelitian (Aşiret \& Dutkun, 2018) setelah dilakukan terapi selama 12 minggu yang dilakukan 2 kali satu minggu dengan durasi 30- 60 menit didapatkan hasil bahwa terapi ini kurang efektif dalam meningkatkan kualitas tidur lansia. Tetapi dari hasil intervensi yang diberikan terapi ini mampu menurunkan tingkat depresi, kesepian dan stress yang di alami lansia. Namun walaupun kurang efektif, sesi terapi kenangan didalam terapi reminiscene memiliki efek positif dalam suasana hati mereka mebuat lansia lebih sering meninggalkan kamar mereka dan memilih lebih sering untuk datang ke sesi melakukan interaksi sosial dan menjalin pertemanan baru, yang hasilnya terjadi peningkatan sosialisasi dan dukungan sosial yang mampu mempengaruhi peningkatan subkomponen kualitas tidur dan mengurangi disfungsi siang hari pada hasil perhitungan PSQI peserta.

7) Acupressure

Acupressure adalah tehnik pijat dengan jari yang di titik beratkan untuk merangsang titik akupuntur di sepanjang garis meridian di permukaan kulit untuk membuka penyumbatan. Menurut pengobatan tradisional tiongkok titik akupuntur adalah lokasi darah dari jeroan dan meridian meresap kedalam permukaan tubuh. Meridians merupakan jalur untuk sirkulasi qi dan darah, menghubungkan organ dan ekstremitas dan menghubungkan energi yang dan yin dapat menjaga kesehatan dan mencegah penyakit. Dimensi masing-masing titik akupuntur adalah 0.3-1.2 cm. Akupresur terbukti mampu mengurangi tekanan psikologis dan meningkatkan kualitas tidur (Y. Chen et al., 2019).

2. Pembahasan

a. Faktor yang mempengaruhi Kualitas Tidur Lansia Panti

Lansia merupakan kelompok umur pada tahap terakhir fase kehidupan. Kelompok yang tergolong lanjut usia akan mengalami proses yang disebut dengan proses penuaan. Proses penuaan ditandai dengan hilangnya integritas fisiologi progresif, yang menyebabkan gangguan fungsi dan kerentanan terhadap kematian (Effendy et al., 2019). Tidur merupakan proses fisiologis yang berfungsi untuk pemulihan yang penting untuk menjaga keseimbangan dan kesehatan tubuh. Lansia yang tinggal di panti menunjukkan gangguan tidur yang lebih kompleks. Dibuktikan dengan lansia yang lebih sering terjaga di malam hari, kesulitan memulai tidur, terbangun di tengah malam dan terbangun lebih cepat di pagi hari. Hal ini lebih sering terjadi pada lansia di panti yang mempunyai kondisi sleep hygiene yang buruk. Gangguan tidur pada lansia bisa berakibat fatal seperti penyakit kardiovaskuler, penurunan kognitif, depresi, dan kualitas hidup yang buruk. (Lee et al., 2020).

Setelah menelusuri lima belas artikel yang di review, lebih dari 7 artikel memaparkan faktor lingkungan menjadi faktor utama atau dominan yang mempengaruhi kualitas tidur lansia di panti. Lansia panti memiliki beraneka ragam sifat, budaya dan kebiasaan. Perbedaan ini mampu memicu kebisingan, mempengaruhi kebersihan kamar serta ikut serta dalam menciptakan suasana nyaman (Yeung 
et al., 2018). Lansia mengeluh tidak bisa tidur karena lingkungan yang kotor dan berbau. $70 \%$ lansia mengaku tidak nyaman dengan bau busuk yang mengganggu tidur mereka. Lansia panti memiliki beraneka ragam sifat, budaya dan kebiasaan. Perbedaan ini mampu memicu kebisingan, mempengaruhi kebersihan kamar serta ikut serta dalam menciptakan suasana nyaman. (Yeung et al., 2018).

Faktor Psikologis yang menyebabkan gangguan tidur pada lansia panti sangat beragam. Antara lain seperti kisah hidup traumatis, masalah rumah tangga terdahulu, kekhawatiran masa kini dan masa depan, mimipi buruk dan perasaan gelisah. Lansia yang stress dan memilih menghabiskan waktu siang nya untuk tidur dapat memicu gangguan tidur di malam hari. Hal ini mempengaruhi kualitas tidur secara negatif. Insomnia yang terjadi pada lansia disebabkan karena kecemasan dan depresi. Depresi memiliki tiga kriteria yaitu depresi ringan ditandai dengan kehilangan minat, kesenangan dan mudah menjadi lelah. Depresi sedangan ditandai dengan mengalami kesulitan untuk meneruskan kegiatan sosial dan pekerjaan, sedangkan depresi berat ditandai dengan gelisah, tegang, kehilangan harga diri, dan keinginan untuk bunuh diri. Depresi juga menyebabkan lansia mengalami gangguan tidur, insomnia termasuk salah satu gangguan tidur yang dijumpai pada lansia yang berdampak pada kualitas tidur (Tao-juan et al., 2019).

Faktor selanjutnya yang juga penting dalam meningkatkan kualitas tidur lansia adalah aktivitas fisik. Menurut penelitian (Iyer et al., 2019)
Lansia Insomnia yang lebih tua menunjukkan distribusi aktivitas fisik yang relatif kurang hal ini terkait dengan imobilitas yang dihubungkan dengan tirah baring. Bedrest kronis mengganggu ritme sikardian / dan ritme waktu tidur. Terlalu lama berbaring di tempat tidur di siang hari menyebabkan episode bangun pendek di malam hari dan kualitas tidur lansia menjadi buruk (Gordon \& Gladman, 2010). Seseorang yang telah lanjut usia akan mengalami kemunduran pada berbagai aspek terutama kemampuan fisik yang dapat mengakibatkan penurunan pada peranan- peranan sosialnya, kemunduran kemampuan fisik ini akan menimbulkan gangguan di dalam hal mencukupi kebutuhan hidupnya sehingga meningkatkan ketergantungan yang memerlukan bantuan orang lain. Hal ini berpengaruh pada aktivitas yang dilakukan oleh lansia, bila aktivitas yang di lakukan berat kadang menyebabkan timbulnya masalah masalah fisik pada lansia tersebut,masalah-masalah fisik yang sering di temukan pada lansia sebagai berikut: mudah jatuh, mudah lelah, dan salah satunya masalah gangguan tidur (insomnia) (Prastyo et al., 2017). Aktivitas fisik berkontribusi dalam mengurangi tekanan psikologis di kalangan lansia karena aktivitas fisik mampu mendorong interaksi psikososial, meningkatkan harga diri, membantu mempertahankan dan meningkatkan fungsi kognitif, dan berfungsi untuk mengurangi frekuensi kambuhnya depresi dan kecemasan. Menurut (Yeung et al., 2018), aktivitas fisik merupakan kegiatan memindahkan/menggerakkan badan seperti berkebun, berjalan, dan menaiki tangga. Namun, aktivitas fisik berbeda 
dengan latihan fisik. Latihan fisik merupakan bagian dari aktivitas fisik yang lebih terstruktur atau terjadwal seperti aerobik dan tai chi. Latihan fisik sebenarnya lebih memengaruhi fungsi kognitif pada lansia. Menurut (Woodall et al., 2014) latihan fisik seperti aerobik akan meningkatkan kemampuan kognitif lansia khususnya bagian kontrol eksekutif dan meningkatkan volume hippocampus. Hippocampus merupakan sentral otak yang sangat penting dalam menyimpan memori.

faktor gizi dan gaya hidup mempunyai keterikatan kuat dengan kualitas tidur lansia panti. Faktor gizi sangat penting karena berdasarkan penelitian (Dewa et al., 2017) mengonsumsi makanan berlemak, siap saji dan makanan tidak sehat secara berlebihan dapat mempengaruhi tidur karena mampu menyebabkan gangguan pencernaan, perut mulas dan tenggorokan panas. Hal ini dapat menyebabkan lansia akan mudah terbangun di malam hari atau sulit untuk kembali memulai tidur dan mempertahankan kualitas tidur yang baik. Asupan gizi ikut menentukan status gizi Lansia. Faktor gaya hidup menurut penelitian (Rodríguez, 2012) lansia akan meninggalkan tempat tidurnya disaat ada kegiatan penting yang diselenggarakan dan lebih memilih berdiam diri diatas tempat tidur seharian untuk bermalas-malasan. Sehingga rata-rata lansia mempunyai aktivitas fisik yang kurang. Sedangakan yang baik adalah dengan menjauhi tempat tidur di siang hari agar di malam hari lansia bisa tidur dengan nyenyak. gaya hidup yang dimiliki lansia ketika di masa muda sangat beragam. Gaya hidup yang tidak sehat di masa muda dapat mempengaruhi fungsi kognitif di kemudian hari. Gaya hidup yang sehat bagi lansia adalah pemenuhan kebutuhan nutrisi yang baik, latihan dan olahraga, istirahat dan tidur yang cukup serta tidak merokok (Marshall \& Hale, 2019).

Lansia merupakan kelompok umur pada tahap terakhir fase kehidupan. Kelompok yang tergolong lanjut usia akan mengalami proses yang disebut dengan proses penuaan. Proses penuaan ditandai dengan hilangnya integritas fisiologi progresif, yang menyebabkan gangguan fungsi dan kerentanan terhadap kematian (Effendy et al., 2019). Tidur merupakan proses fisiologis yang berfungsi untuk pemulihan yang pernting untuk menjaga keseimbangan dan kesehatan tubuh. Lansia yang tinggal di panti menunjukkan gangguan tidur yang lebih kompleks. dibuktikan dengan lansia yang lebih sering terjaga di malam hari, kesulitan memulai tidur, terbangun di tengah malam dan terbangun lebih cepat di pagi hari. Hal ini lebih sering terjadi pada lansia di panti yang mempunyai kondisi sleep hygiene yang buruk. Gangguan tidur pada lansia bisa berakibat fatal seperti penyakit kardiovaskuler, penurunan kognitif, depresi, dan kualitas hidup yang buruk. (Lee et al., 2020).

Setelah menelusuri lima belas artikel yang di review, lebih dari 7 artikel memaparkan faktor lingkungan menjadi faktor utama atau dominan yang mempengaruhi kualitas tidur lansia di panti. Lansia panti memiliki beraneka ragam sifat, budaya dan kebiasaan. Perbedaan ini mampu memicu kebisingan, mempengaruhi kebersihan kamar serta ikut serta dalam menciptakan suasana nyaman (Yeung et al., 2018). Lansia mengeluh tidak bisa tidur karena lingkungan yang 
kotor dan berbau. $70 \%$ lansia mengaku tidak nyaman dengan bau busuk yang mengganggu tidur mereka. Lansia panti memiliki beraneka ragam sifat, budaya dan kebiasaan. Perbedaan ini mampu memicu kebisingan, mempengaruhi kebersihan kamar serta ikut serta dalam menciptakan suasana nyaman (Yeung et al., 2018).

Faktor Psikologis yang menyebabkan gangguan tidur pada lansia panti sangat beragam. Antara lain seperti kisah hidup traumatis, masalah rumah tangga terdahulu, kekhawatiran masa kini dan masa depan, mimipi buruk dan perasaan gelisah. Lansia yang stress dan memilih menghabiskan waktu siang nya untuk tidur dapat memicu gangguan tidur di malam hari. Hal ini mempengaruhi kualitas tidur secara negatif. Insomnia yang terjadi pada lansia disebabkan karena kecemasan dan depresi. Depresi memiliki tiga kriteria yaitu depresi ringan ditandai dengan kehilangan minat, kesenangan dan mudah menjadi lelah. Depresi sedangan ditandai dengan mengalami kesulitan untuk meneruskan kegiatan sosial dan pekerjaan, sedangkan depresi berat ditandai dengan gelisah, tegang, kehilangan harga diri, dan keinginan untuk bunuh diri. Depresi juga menyebabkan lansia mengalami gangguan tidur, insomnia termasuk salah satu gangguan tidur yang dijumpai pada lansia yang berdampak pada kualitas tidur (Tao-juan et al., 2019)

Faktor selanjutnya yang juga penting dalam meningkatkan kualitas tidur lansia adalah aktivitas fisik. Menurut penelitian (Iyer et al., 2019) Lansia Insomnia yang lebih tua menunjukkan distribusi aktivitas fisik yang relatif kurang hal ini terkait dengan imobilitas yang dihubungkan dengan tirah baring. Bedrest kronis mengganggu ritme sikardian / dan ritme waktu tidur. Terlalu lama berbaring di tempat tidur di siang hari menyebabkan episode bangun pendek di malam hari dan kualitas tidur lansia menjadi buruk (Gordon \& Gladman, 2010). Seseorang yang telah lanjut usia akan mengalami kemunduran pada berbagai aspek terutama kemampuan fisik yang dapat mengakibatkan penurunan pada peranan- peranan sosialnya, kemunduran kemampuan fisik ini akan menimbulkan gangguan di dalam hal mencukupi kebutuhan hidupnya sehingga meningkatkan ketergantungan yang memerlukan bantuan orang lain. Hal ini berpengaruh pada aktivitas yang dilakukan oleh lansia, bila aktivitas yang di lakukan berat kadang menyebabkan timbulnya masalah masalah fisik pada lansia tersebut, masalah-masalah fisik yang sering di temukan pada lansia sebagai berikut: mudah jatuh, mudah lelah, dan salah satunya masalah gangguan tidur (insomnia) (Prastyo et al., 2017). Aktivitas fisik berkontribusi dalam mengurangi tekanan psikologis di kalangan lansia karena aktivitas fisik mampu mendorong interaksi psikososial, meningkatkan harga diri, membantu mempertahankan dan meningkatkan fungsi kognitif dan berfungsi untuk mengurangi frekuensi kambuhnya depresi dan kecemasan. Menurut (Yeung et al., 2018), aktivitas fisik merupakan kegiatan memindahkan/menggerakkan badan seperti berkebun, berjalan, dan menaiki tangga. Namun, aktivitas fisik berbeda dengan latihan fisik. Latihan fisik merupakan bagian dari aktivitas fisik 
yang lebih terstruktur atau terjadwal seperti aerobik dan tai chi. Latihan fisik sebenarnya lebih memengaruhi fungsi kognitif pada lansia. Menurut (Browne et al., 2013) latihan fisik seperti aerobik akan meningkatkan kemampuan kognitif lansia khususnya bagian kontrol eksekutif dan meningkatkan volume hippocampus. Hippocampus merupakan sentral otak yang sangat penting dalam menyimpan memori.

Faktor gizi dan gaya hidup mempunyai keterikatan kuat dengan kualitas tidur lansia panti. Faktor gizi sangat penting karena berdasarkan penelitian (Dewa et al., 2017) mengonsumsi makanan berlemak, siap saji dan makanan tidak sehat secara berlebihan dapat mempengaruhi tidur karena mampu menyebabkan gangguan pencernaan, perut mulas dan tenggorokan panas. Hal ini dapat menyebabkan lansia akan mudah terbangun di malam hari atau sulit untuk kembali memulai tidur dan mempertahankan kualitas tidur yang baik. Asupan gizi ikut menentukan status gizi Lansia.

Faktor gaya hidup menurut penelitian (Rodríguez, 2012) lansia akan meninggalkan tempat tidurnya disaat ada kegiatan penting yang diselenggarakan dan lebih memilih berdiam diri diatas tempat tidur seharian untuk bermalas-malasan. Sehingga rata-rata lansia mempunyai aktivitas fisik yang kurang. Sedangakan yang baik adalah dengan menjauhi tempat tidur di siang hari agar di malam hari lansia bisa tidur dengan nyenyak. gaya hidup yang dimiliki lansia ketika di masa muda sangat beragam. Gaya hidup yang tidak sehat di masa muda dapat mempengaruhi fungsi kognitif di kemudian hari. Gaya hidup yang sehat bagi lansia adalah pemenuhan kebutuhan nutrisi yang baik, latihan dan olahraga, istirahat dan tidur yang cukup serta tidak merokok (Marshall \& Hale, 2019).

b. Jenis Intervensi yang digunakan untuk meningkatkan Kualitas Tidur lansia di panti

Faktor lingkungan menjadi faktor utama atau dominan yang mempengaruhi kualitas tidur lansia di panti (Yeung et al., 2018). Hasil penelusuran artikel menunjukkan bahwa sembilan dari lima belas artikel yang sudah di review mempermasalahkan lingkungan dan aktivitas fisik sebagai faktor paling berpengaruh terhadap gangguan tidur lansia. Intervensi yang dibahas penulis untuk mengurangi gangguan tidur dan meningkatkan kualitas tidur lansia pada literature review ini adalah Brain gym, therapeutic touch, cognitive training, footbath therapy, aromatheraphy, reminiscene therapy dan acupressure.

Aromatheraphy adalah salah satu cara pengobatan penyakit dengan menggunakan bau-bauan yang umumnya berasal dari tumbuhtumbuhan yang berbau harum, gurih, dan enak yang disebut minyak asiri. Aroma terapi suatu cara perawatan tubuh dan penyembuhan penyakit dengan minyak essensial (essential oil). Mekanisme aroma terapi adalah dimulai dari aroma yang dihirup memasuki hidung dan berhubungan dengan silia, penerima di dalam silia dihubungkan dengan alat penghirup yang berada di ujung saluran bau. Baubauan diubah oleh silia menjadi impuls listrik yang dipancarkan ke otak melalui sistem penghirup. Semua impulsi mencapai sistem limbik di hipotalamus selanjutnya akan meningkatkan gelombang alfa di dalam 
otak dan akan membantu kita untuk merasa rileks. Posisi rileks akan menurunkan stimulus ke sistem aktivasi retikular (SAR), yang berlokasi pada batang otak teratas yang dapat mempertahankan kewaspadaan dan terjaga akan diambil alih oleh bagian otak yang lain yang disebut BSR (Bulbar Synchronizing Regoin) yang fungsinya berkebaikan dengan SAR, sehingga bisa menyebabkan tidur yang diharapkan akan dapat meningkatkan kualitas tidur. Pada penelitian (Faydali \& Çetinkaya, 2018) Intervensi diberikan dengan meneteskan minyak aromatheraphy sebanyak 3 tetes $(0,3 \mathrm{ml})$ pada kertas tissue dan dilakukan sekitar pukul 19.30-20.30 selama 15 menit dalam kurun waktu 28 hari berturut-turut. Dari intervensi tersebut ditemukan hasil uji statistik $\mathrm{t}$ independen terhadap perbedaan kualitas tidur antara kelompok kontrol dan intervensi menunjukkan terdapat perbedaan yang signifikan terhadap kualitas tidur setelah diberikan relaksasi aromaterapi jasmine pada kelompok kontrol dan kelompok intervensi. Berdasarkan hasil penelitian, peneliti memperlihatkan bahwa penggunaan aromaterapi sebagai intervensi untuk manajemen tidur pada lansia telah memberikan manfaat yang nyata. Efek sedatif dan relaksasi yang ditimbulkan dari aromaterapi jasmine menyebabkan perbaikan kondisi emosional lansia sehingga lansia akan lebih rileks dan mendapatkan tidur yang nyenyak di malam hari serta bangun dengan segar di pagi hari. Pada penelitian (Lee et al., 2020) Penelitian di lakukan dengan teknik inhalat uap yaitu dengan cara menambahkan 5-6 tetes minyak aroma terapi lavender kedalam mangkok yang berisi air mendidih $\pm 5 \mathrm{cc}$ di atas tungku pemanas, kemudian di letakkan didekat lansia yang akan tidur selama 30 menit sehingga aromanya akan dihirup oleh lansia yang mengalami gangguan tidur (insomnia). Teknik pemberian aroma terapi lavender secara inhalat uap akan lebih efektif karena mekanisme kerjanya, butiran melekul uap yang sangat kecil dengan mudah dapat diserap melalui aliran darah hingga pembuluh kapiler darah di seluruh jaringan tubuh. Zat-zat aktif yang terdapat dalam minyak lavender ini kemudian diedarkan ke seluruh jaringan tubuh, sehingga akan lebih mudah mencapai sasaran lokasi yang diobati

Brain Gym Merupakan senam otak atau salah satu senam lansia yang mampu merangsang penurunan aktifitas saraf simpatis dan peningkatan aktifitas saraf para simpatis yang berpengaruh pada penurunan hormon adrenalin, norepinefrin dan katekolamin serta vasodilatasi pada pembuluh darah yang mengakibatkan transport oksigen ke seluruh tubuh terutama otak lancar sehingga dapat menurunkan tekanan darah dan nadi menjadi normal. Senam otak mampu mengembalikan posisi dan kelenturan sistem saraf dan aliran darah. Senam mampu memaksimalkan supply oksigen ke otak, mampu menjaga sistem kesegaran tubuh serta sistem pembuangan energi negatif dari dalam tubuh. Senam lansia merupakan kombinasi dari gerakan otot dan teknik pernafasan. Teknik pernapasan yang dilakukan secara sadar dan menggunakan diafragma, memungkinkan abdomen terangkat perlahan dan dada mengembang penuh. Teknik pernapasan tersebut, mampu 
memberikan pijatan pada jantung yang menguntungkan akibat naik turunnya diafragma, membuka sumbatansumbatan dan memperlancar aliran darah ke jantung serta meningkatkan aliran darah ke seluruh tubuh. Menurut (Effendy et al., 2019) Brain Gym dilakukan untuk meningkatkan perhatian, memori, dan ketrampilan akademik. Pada penelitian ini intervensi menuntut partisipan untuk dilibatkan dalam berbagai gerakan seperti mengkoordinasikan tangan, mata, telinga, dan seluruh tubuh secara terstruktur. Intervensi dilakukan dalam satu bulan dengan durasi 15-20 menit yang dilaksanakan seminggu 4 kali.

telah terbukti efektif dalam meningkatkan kualitas tidur karena mampu menurunkan suhu inti tubuh melalui vasodilatasi perifer. Terapi Footbath mampu meningkatkan kualitas tidur dengan mengurangi latensi onset tidur, meningkatkan fase tidur NREM, dan mengurangi tidur REM. Selain itu terapi ini mudah dilakukan dan hemat biaya. Menurut penelitian yang dilakukan (Lee et al., 2020) rendam kaki secara baik dapat meningkatkan kualitas tidur kalangan lansia. Menurut penelitian tersebut lansia yang belum menjalani terapi rendam kaki hanya memiliki waktu tidur efektif sekitar 4,88 jam. Namun setelah dilakukan terapi rendam kaki kuantitas waktu tidur lansia kemudian bertambah menjadi 6,20 jam. Terapi rendam kaki dengan air hangat adalah salah satu terapi yang dapat digunakan untuk mengatasi permasalahan gangguan tidur.Terapi ini dapat dilakukan dengan merendam kaki pada air dengan suhu $37-39^{\circ} \mathrm{C}$ setiap malam sebelum tidur selama 1 bulan. Di dalam penelitian ini juga diterangkan bahwa dengan merendamkan kaki ke dalam air hangat selama beberapa menit dapat meningkatkan kualitas tidur. Peningkatan kualitas tidur ini terjadi akibat kondisi tubuh yang lebih tenang dan relax. Kondisi ini kemudian membuat seseorang dapat tidur dengan nyaman dan nyanyak.

Latihan kognitif merupakan suatu pengobatan rehabilitasi yang berfungsi untuk meningkatkan kemampuan individu yang mengalami masalah neurologis karena fenomena penyakit atau faktor penuaan. Latihan kognitif digunakan sebagai alat untuk membantu mencapai tujuan terapeutik yang ditargetkan seperti meningkatkan harga diri dan melatih lansia untuk mengembangkan strategi pemecahan masalah. Tujuan dari latihan kognitif adalah untuk meningkatkan memori, perhatian, presepsi, penalaran, perencanaan, penilaian pembelajaran umum dan fungsi otak. Menurut penelitian (Almondes et al., 2017) latihan kognitif dapat meningkatkan kualitas tidur karena latihan kognitif mempunyai efek menguntungkan tentang arsitektur tidur, yang dapat meningkatkan kualitas tidur secara keselurahan. Latihan kognitif disebut sebagai mekanisme kunci untuk pemulihan korteks prefrontal, bisa diartikan sebagai katalisator yang memaksa otak untuk memiliki lebih banyak episode tidur untuk mencapai tahan REM. Perubahan arsitektur tidur dan peningkatan tahap REM memungkinkan lansia untuk mendapatkan tidur restoratif sehingga kemungkinan mengantuk di siang hari berkurang sehingga kualitas tidur di malam hari meningkat. Menurut (Xiao et al., 2020) dengan dilakukannya 
senam otak pada pagi hari akan memperlancar transport oksigen ke seluruh tubuh terutama otak,senam mampu mengembalikan posisi kelenturan saraf dan aliran darah, sehingga dapat meningkatkan relaksasi lansia serta sekresi melatonin yang optimal dan pengaruh beta endhorphindan membantu peningkatan pemenuhan kebutuhan tidur lansia. Menurut penelitian Team (2014) dengan melakukan program aktivitas fisik jangka pendek seperti latihan fisik dapat membawa perbaikan yang berarti dalam kinerja fungsi kognitif lansia. Selain itu, dengan melakukan aktivitas fisik secara rutin dan berkala termasuk berjalan kaki akan membuat fungsi kognitif menjadi lebih baik. Hal ini karena aktivitas fisik dapat mempertahankan aliran darah yang optimal dan mengantarkan nutrisi ke otak. Apabila lansia tidak melakukan aktivitas fisik secara rutin maka aliran darah ke otak menurun, dan akan menyebabkan otak kekurangan oksigen.

Therapeutic touch atau terapi sentuhan merupakan terapi pengobatan holistik yang validitasnya sudah terbukti. Terapi sentuhan memungkinkan individu untuk menemukan keseimbangan batin yang berfungsi untuk mengurangi stress, terapi ini merupakan pengobatan sederhana dan non invasif tanpa biaya, tanpa efek samping dan tindakan medis (Munly, 2015). Terapi sentuhan terbukti memiliki efek seperti mengurangi rasa sakit, kecemasan, depresi dan kelelahan, meningkatkan kualitas hidup dan kualitas tidur, mengatur tekanan darah dan jantung, memberikan relaksasi dan kenyamanan. Menurut penelitian
(Yücel et al., 2020) terapi sentuhan efektif dalam mengurangi nyeri dan meningkatkan rasa nyaman, sehingga dapat meningkatkan kualitas tidur. Pada penelitian ini terapi dilakukan selama 10 menit pada rentang waktu pukul 18.00-22.00.

Acupressure adalah tehnik pijat dengan jari yang di titik beratkan untuk merangsang titik akupuntur di sepanjang garis meridian di permukaan kulit untuk membuka penyumbatan ( $\mathrm{T}$. Chen et al., 2020). Menurut pengobatan tradisional tiongkok titik akupuntur adalah lokasi darah dari jeroan dan meridian meresap kedalam permukaan tubuh. Meridians merupakan jalur untuk sirkulasi qi dan darah, menghubungkan organ dan ekstremitas dan menghubungkan energi yang dan yin dapat menjaga kesehatan dan mencegah penyakit. Dimensi masingmasing titik akupuntur adalah 0.3-1.2 $\mathrm{cm}$. Akupresur terbukti mampu mengurangi tekanan psikologis dan meningkatkan kualitas tidur. Menurut penelitian (T. Chen et al., 2020) sebelum intervensi lansis mengalami masalah tidur yang parah dengan skor (C-PSQI >13) namun setelah dilakukan intervensi menunjukkan adanya peningkatan yang signifikan. Selain itu terapi ini mampu meningkatkan efektivitas latensi tidur, durasi tidur, kuantitas serta kualitas tidur. Akupresur bekerja dengan cara menerapkan tekanan ke titik akupressure yang mampu melepaskan neurotransmitter yang menyampaikan sinyal sepanjang neuron atau mengaktifkan sumbu hipotalamushipofisis-adrenal lalu mengatur fungsi endokrin, sehingga menyebabkan otot rileks dan mampu membuat lansia 
mengantuk cepat tertidur dan tetap tertidur.

\section{Kesimpulan}

Perubahan kualitas tidur pada lansia disebabkan oleh kemampuan fisik lansia yang semakin menurun. Kemampuan fisik menurun karena kemampuan organ dalam tubuh yang menurun, seperti jantung, paruparu, dan ginjal. Penurunan kemampuan organ mengakibatkan daya tahan tubuh dan kekebalan tubuh turut terpengaruh mempengaruhi kuantitas dan kualitas tidur. Hasil Literature review ini menunjukkan faktor yang mempengaruhi kualitas tidur lansia di panti adalah faktor lingkungan, faktot stress psikologi, faktor gizi, faktor gaya hidup dan faktor olahraga/aktivitas fisik. Sementara cara meningkatkan kualitas tidur adalah Brain gym, therapeutic touch, cognitive training, footbath therapy, aromatheraphy, reminiscene therapy dan acupressure.

\section{BIBLIOGRAFI}

Almondes, K. M. De, Leonardo, M. E. M., \& Moreira, A. M. S. (2017). Effects Of A Cognitive Training Program And Sleep Hygiene For Executive Functions And Sleep Quality In Healthy Elderly. Dementia \& Neuropsychologia, 11(1), 69-78.

Aşiret, G. D., \& Dutkun, M. (2018). The Effect Of Reminiscence Therapy On The Adaptation Of Elderly Women To Old Age: A Randomized Clinical Trial. Complementary Therapies In Medicine, $41,124-129$.

Brewster, M. E., Velez, B. L., Breslow, A. S., \& Geiger, E. F. (2019). Unpacking Body Image Concerns And Disordered Eating For Transgender Women: The Roles Of Sexual Objectification And Minority Stress. Journal Of Counseling Psychology, 66(2), 131.
Browne, M. A., Niven, S. J., Galloway, T. S., Rowland, S. J., \& Thompson, R. C. (2013). Microplastic Moves Pollutants And Additives To Worms, Reducing Functions Linked To Health And Biodiversity. Current Biology, 23(23), 2388-2392.

Chen, B. (2019). Geometry Of Submanifolds. Courier Dover Publications.

Chen, T., Wu, D. I., Chen, H., Yan, W., Yang, D., Chen, G., Ma, K., Xu, D., Yu, H., \& Wang, H. (2020). Clinical Characteristics Of 113 Deceased Patients With Coronavirus Disease 2019: Retrospective Study. Bmj, 368.

Chen, Y., Chen, X.-Y., Du, H.-T., Zhang, X., Ma, Y.-M., Chen, J.-C., Ye, J.-W., Jiang, X.-R., \& Chen, G.-Q. (2019). Chromosome Engineering Of The Tca Cycle In Halomonas Bluephagenesis For Production Of Copolymers Of 3Hydroxybutyrate And 3Hydroxyvalerate (Phbv). Metabolic Engineering, 54, 69-82.

Cherukuri, S., Bajo, M., Colussi, G., Corciulo, R., Fessi, H., Ficheux, M., Slon, M., Weinhandl, E., \& Borman, N. (2018). Home Hemodialysis Treatment And Outcomes: Retrospective Analysis Of The Knowledge To Improve Home Dialysis Network In Europe (Kihdney) Cohort. Bmc Nephrology, 19(1), 1-10.

Dewa, C. S., Loong, D., Bonato, S., \& Trojanowski, L. (2017). The Relationship Between Physician Burnout And Quality Of Healthcare In Terms Of Safety And Acceptability: A Systematic Review. Bmj Open, 7(6), E015141.

Effendy, E., Prasanty, N., \& Utami, N. (2019). The Effects Of Brain Gym On Quality Of Sleep, Anxiety In Elderly At Nursing Home Care Case Medan. Open Access Macedonian Journal Of Medical Sciences, 7(16), 2595. 
Elvina, R., Musyarofah, R., \& Putri, R. A. (2017). Evaluasi Penggunaan Obat Antimuntah Pada Pasien Anak Penderita Kanker Di Rumah Sakit Kanker Dharmais Jakarta Periode Juni-Juli 2016. Media Farmasi: Jurnal Ilmu Farmasi, 14(1), 91-102.

Faydali, S., \& Çetinkaya, F. (2018). The Effect Of Aromatherapy On Sleep Quality Of Elderly People Residing In A Nursing Home. Holistic Nursing Practice, 32(1), 8-16.

Gordon, A., \& Gladman, J. R. F. (2010). Sleep In Care Homes. Reviews In Clinical Gerontology, 20(4).

Iyer, L., Yesodharan, R., \& Nayak, A. K. (2019). Prevalence Of Insomnia, And Sleep Hygiene Techniques Practiced Among Elderly Residing In Selected Old Age Homes Of Udupi And Dakshina Kannada District, Karnataka. Indian Journal Of Public Health, 10(9), 463.

Kim, G.-W., Kang, G., Kim, J., Lee, G.-Y., Kim, H. Il, Pyeon, L., Lee, J., \& Park, T. (2016). Dopant-Free Polymeric Hole Transport Materials For Highly Efficient And Stable Perovskite Solar Cells. Energy \& Environmental Science, 9(7), 2326-2333.

Lee, J., Kim, D. E., Griffin, P., Sheehan, P. W., Kim, D., Musiek, E. S., \& Yoon, S. (2020). Inhibition Of Rev - Erbs Stimulates Microglial Amyloid - Beta Clearance And Reduces Amyloid Plaque Deposition In The 5xfad Mouse Model Of Alzheimer's Disease. Aging Cell, 19(2), E13078.

Li, Y., \& Jiang, S. (2020). Multi-Focus Image Fusion Using Geometric Algebra Based Discrete Fourier Transform. Ieee Access, 8, 60019-60028.

Marshall, K., \& Hale, D. (2019). Older Adults And The Opioid Crisis. Home Healthcare Now, 37(2), 117.
Martin, G. M., Kandasamy, B., Dimaio, F., Yoshioka, C., \& Shyng, S.-L. (2017). Anti-Diabetic Drug Binding Site In A Mammalian Katp Channel Revealed By Cryo-Em. Elife, 6, E31054.

Morehen, S., Smeuninx, B., Perkins, M., Morgan, P., \& Breen, L. (2020). PreSleep Casein Protein Ingestion Does Not Impact Next-Day Appetite, Energy Intake And Metabolism In Older Individuals. Nutrients, 12(1), 90.

Munly, K. (2015). Understanding Adult Foster Care Provider Experiences. Virginia Polytechnic Institute And State University.

Nursalam, N., Fibriansari, R. D., Yuwono, S. R., Hadi, M., Efendi, F., \& Bushy, A. (2018). Development Of An Empowerment Model For Burnout Syndrome And Quality Of Nursing Work Life In Indonesia. International Journal Of Nursing Sciences, 5(4), 390395.

Organization, W. H. (2015). Who Report On Global Surveillance Of Epidemic-Prone Infectious Diseases: Dengue And Dengue Haemorrhagic Fever, 2014 [Cited 2014 Jul 21].

Prastyo, B. W., Sugiyanto, S., \& Doewes, M. (2017). The Development Model Of The Basic Techniques Of Exercise And Physical Exercise On Futsal Players Level Intermediate. European Journal Of Physical Education And Sport Science.

Ri, K. K. (2012). Petunjuk Teknis Pemberantasan Sarang Nyamuk Demam Berdarah Dengue (Psn Dbd) Oleh Juru Pemantau Jentik (Jumantik). Depkes Ri, Jakarta.

Rodríguez, M. A. (2012). Inhibition Of Localized Corrosion In Chromium Containing Stainless Alloys. Corrosion Reviews, 30(1-2), 19-32. 
Štefan, L., Vrgoč, G., Rupčić, T., Sporiš, G., \& Sekulić, D. (2018). Sleep Duration And Sleep Quality Are Associated With Physical Activity In Elderly People Living In Nursing Homes. International Journal Of Environmental Research And Public Health, 15(11), 2512.

Tao-Juan, Z., Chu-Shu, P. I., Man, Y. A. O., Cheng, Y., Fang, Y. E., Jian-Ping, C., \& Zhi-Sheng, Z. (2019). Effects Of Coating Agent Hanyubaomu Seedling Raising On Rice Grain Yield In Southeast Hubei Province. Hubei Agricultural Sciences, 58(23), 36.

Thiele, S., Balestro, F., Ballou, R., Klyatskaya, S., Ruben, M., \& Wernsdorfer, W. (2014). Electrically Driven Nuclear Spin Resonance In Single-Molecule Magnets. Science, 344(6188), 1135-1138.

Woodall, L. C., Sanchez-Vidal, A., Canals, M., Paterson, G. L. J., Coppock, R., Sleight, V., Calafat, A., Rogers, A. D., Narayanaswamy, B. E., \& Thompson, R. C. (2014). The Deep Sea Is A Major Sink For Microplastic Debris. Royal Society Open Science, 1(4), 140317.

Xiao, S., Shimura, D., Baum, R., Hernandez, D. M., Agvanian, S., Nagaoka, Y., Katsumata, M., Lampe, P. D., Kleber, A. G., \& Hong, T. (2020). Auxiliary
Trafficking Subunit Gja1-20k Protects Connexin-43 From Degradation And Limits Ventricular Arrhythmias. The Journal of Clinical Investigation, 130(9).

Yeung, S., Russakovsky, O., Jin, N., Andriluka, M., Mori, G., \& Fei-Fei, L. (2018). Every Moment Counts: Dense Detailed Labeling Of Actions In Complex Videos. International Journal Of Computer Vision, 126(2), 375-389.

Yücel, Ş. Ç., Arslan, G. G., \& Bagci, H. (2020). Effects Of Hand Massage And Therapeutic Touch On Comfort And Anxiety Living In A Nursing Home In Turkey: A Randomized Controlled Trial. Journal Of Religion And Health, 59(1), 351-364.

Zhu, N., Zhang, D., Wang, W., Li, X., Yang, B., Song, J., Zhao, X., Huang, B., Shi, W., \& Lu, R. (2020). A Novel Coronavirus From Patients With Pneumonia In China, 2019. New England Journal Of Medicine. 